\section{Root and Shoot Growth Periodicity of Kalmia latifolia 'Sarah' and Ilex crenata 'Compacta'}

\author{
Amy N. Wright ${ }^{1}$, Stuart L. Warren ${ }^{2}$, Frank A. Blazich ${ }^{2}$, and Udo Blum ${ }^{3}$ \\ Department of Horticultural Science North Carolina State University, Raleigh, \\ NC 27695-7609
}

\author{
Additional index words. mountain laurel, Japanese holly, transplanting, root : shoot ratio, \\ woody ornamental, container-grown
}

\begin{abstract}
The length of time between transplanting and subsequent new root initiation, root growth rates, and root growth periodicity influences the ability of woody ornamentals to survive transplanting and become established in the landscape. Research was conducted to compare root growth of a difficult-to-transplant species, Kalmia latifolia L. (mountain laurel), to that of an easy-to-transplant species, Ilex crenata Thunb. (Japanese holly), over the course of 1 year. Micropropagated liners of 'Sarah' mountain laurel and rooted stem cuttings of 'Compacta' holly were potted in 3 -L containers. Plants were grown in a greenhouse from May to September, at which time they were moved outside to a gravel pad, where they remained until the following May. Destructive plant harvests were conducted every 2 to 4 weeks for 1 year. At each harvest, leaf area, shoot dry weight (stems and leaves), root length, root area, and root dry weight were determined. Throughout the experiment, shoot dry weight and leaf area were similar for the two species. New root growth of 'Compacta' holly and 'Sarah' mountain laurel was measurable 15 and 30 days after potting, respectively. Root length and root area of 'Sarah' mountain laurel increased during May through December but decreased during January through May. Root length and root area of 'Compacta' holly increased linearly throughout the course of the experiment. Final root : shoot ratio of 'Sarah' mountain laurel was one-ninth that of 'Compacta' holly. Results suggest that poor transplant performance of mountain laurel in the landscape may be related to its slow rate of root growth.
\end{abstract}

When a plant is transplanted into the landscape from a container, many factors affect its survival. Of these, root growth into the surrounding soil appears to be one of the most critical (Watson and Himelick, 1997). Root growth following transplanting is necessary if the plant is to obtain water and mineral nutrients necessary for plant growth and development. The rate of root growth and root growth periodicity vary with species and environmental conditions (Head, 1966; Rogers and Head, 1969). Norway maple (Acer platanoides L.), green ash (Fraxinus pennsylvanica Marsh.), and ginkgo (Ginkgo biloba L.) exhibited differences in root regeneration following transplanting and responded differently to season of transplanting (Watson and Himelick, 1982). There is some evidence that the time between transplanting and new root growth is longer for those species considered difficult to transplant (Struve et al., 1984).

Received for publication 15 Nov. 2002. Accepted for publication 8 May 2003.This research was funded in part by the North Carolina Agricultural Research Service (NCARS), Raleigh, NC 27695-7643. From a thesis submitted by A.N.W. in partial fulfillmen of the requirements for the $\mathrm{PhD}$ degree. Appreciation is extended to: William M. Reece and Juan R. Acedo for technical assistance, William H. Swallow for statistical assistance, and Briggs Nursery, Inc., Olympia, Wash., for supplying plant material.

${ }^{1}$ Assistant Professor. Current address: Dept. of Horticulture, Auburn Univ., Auburn, AL 36849.

${ }^{2}$ Professor.

${ }^{3}$ Professor, Dept. of Botany.
Traditionally, woody species considered difficult to transplant are those with taproot systems, whereas species with fibrous root systems are often considered easy to transplant (Pirone, 1978; Struve and Moser, 1984). Although mountain laurel, an evergreen shrub native to the eastern United States, produces a fibrous root system, it frequently does not survive transplanting from containers into the landscape, even in areas to which it is indigenous (Jaynes, 1997). Characterizing rate and periodicity of root growth of mountain laurel with subsequent comparison to root growth of an easy to transplant species, such as Japanese holly, may provide insight into the difficulty associated with landscape establishment of this ericaceous species. Therefore, the objective of this research was to compare the rate and periodicity of root growth of mountain laurel and Japanese holly over the course of a year.

\section{Materials and Methods}

Six-month-old micropropagated liners of 'Sarah' mountain laurel and 1-year-old rooted stem cuttings of 'Compacta' holly were repotted into 3-L containers in May 1999. Plants were potted in arcillite, a calcined montmorillonite and illite clay (Turface-MVP ${ }^{\mathrm{TM}}$; Profile Products, Buffalo Grove, Ill.). Arcillite is a coarse-textured substrate that is removed easily to facilitate harvest of roots and is preferred over sand because of its mineral nutrient and water-holding properties (Hiller and Koller, 1979). Prior to potting, roots of all plants were dyed by submerging each root system (substrate intact) in a solution of $0.5 \%(\mathrm{w} / \mathrm{v})$ methylene blue for $10 \mathrm{~s}$. This dye provides an effective way to distinguish between root tissue present at potting (blue) and new root tissue produced after potting (white) (Arnold and Young, 1990). Plants were potted with the original substrate intact to minimize injury to the root system and to simulate transplanting of an undisturbed, containerized rootball into the landscape. Upon potting, plants were immediately irrigated to remove any excess dye that could possibly be transferred to new roots.

Plants were grown in the Dept. of Horticultural Science greenhouses, North Carolina State Univ., Raleigh, under natural photoperiod and irradiance with temperatures of $24{ }^{\circ} \mathrm{C}$ day $/ 16{ }^{\circ} \mathrm{C}$ night. In Sept. 1999 , plants were moved outdoors to a gravel pad at the Horticulture Field Laboratory, Raleigh, for the remainder of the study to allow the plants to experience seasonal changes in temperature. To prevent winter injury, plants were covered with white polyethylene from Dec. 1999 to Feb. 2000

While in the greenhouse, plants were fertilized three times weekly with a solution of 100 $\mathrm{mg} \cdot \mathrm{L}^{-1} \mathrm{~N}$ using Peters ${ }^{\mathrm{TM}}$ (Scotts Co., Marysville, Ohio) $20 \mathrm{~N}-8.8 \mathrm{P}-16.6 \mathrm{~K}$ with trace elements. Calcium (as $\mathrm{CaCO}_{2} \mathrm{H}$ ) at $50 \mathrm{mg} \cdot \mathrm{L}^{-1}$ and $\mathrm{Mg}\left(\right.$ as $\left.\mathrm{MgSO}_{4}\right)$ at $25 \mathrm{mg} \cdot \mathrm{L}^{-1}$ were also added to the fertilizer solution. Once per week plants received foliar application of iron chelate at 10 $\mathrm{mg} \cdot \mathrm{L}^{-1}$, applied using a handheld mist sprayer to run off. While the plants were outdoors, the same liquid fertilizer was applied once weekly except during December through February, when no fertilizer was applied. Foliar iron application was discontinued in September. Supplemental irrigation (tap water) was applied as needed throughout the experiment.

Experimental variables were species and harvest date [days after potting (DAP)], which were arranged in a randomized complete-block design with five blocks. Each block contained 50 plants of each species, arranged randomly. Destructive plant harvests were conducted every 2 to 4 weeks for 1 year (16 total harvests; Table 1) by randomly selecting one plant of each species from each block. At all harvests

Table 1. Harvest dates and corresponding days after potting (DAP).

\begin{tabular}{lrr}
\hline Harvest & DAP & Date \\
\hline--- & 0 & 17 May 1999 \\
1 & 15 & 6 June 1999 \\
2 & 30 & 16 June 1999 \\
3 & 44 & 30 June 1999 \\
4 & 64 & 20 July 1999 \\
5 & 88 & 13 Aug. 1999 \\
6 & 108 & 21 Sept. 1999 \\
7 & 143 & 7 Oct. 1999 \\
8 & 158 & 22 Oct. 1999 \\
9 & 178 & 11 Nov. 1999 \\
10 & 203 & 6 Dec. 1999 \\
11 & 249 & 21 Jan. 2000 \\
12 & 284 & 25 Feb. 2000 \\
13 & 319 & 31 Mar. 2000 \\
14 & 347 & 28 Apr. 2000 \\
15 & 361 & 12 May 2000 \\
16 & 374 & 25 May 2000 \\
\hline
\end{tabular}


each plant was separated into shoots (aerial portion) and roots. Roots produced outside of the original root ball from the start of the experiment (roots that were white and lacked blue dye, non-dyed) were washed free of arcillite and removed from the original root ball, and total length and surface area of these roots were measured [hereafter referred to as root length (RL) and root area (RA)] using a Monochrome AgVision System 286 Image Analyzer(Decagon Devices, Pullman, Wash.). Any dead roots were present in such small amounts that these were not separated from living roots at harvest. Total leaf area (LA) was measured using a LI-COR 3000 leaf area meter (LI-COR, Lincoln, Nebr.). All harvested tissue was dried at $70^{\circ} \mathrm{C}$ for at least $72 \mathrm{~h}$, and dry weights of non-dyed roots (RDW) and shoots (SDW) were recorded. Open spaces in a block created by plant harvests were filled with excess plants that had been included in each block. As a result, plants harvested at the end of the study had similar container-tocontainer contact as those plants harvested at the beginning of the experiment.

Beginning Oct. 1999, root length and root area were determined using a subsampling technique, since growth of new root tissue had become too extensive for measurement of total new RL and RA. For each harvested plant, a subsample (about one-quarter) of the non-dyed roots was removed, and length, area, and DW were determined. Total DW of all non-dyed roots was also determined. For each harvest, length and area of the root subsample were regressed on DW of the root subsample, and the resulting equation was used to calculate total RL or total RA for a given total root DW value. All regressions had an $R^{2} \geq 0.77$, with a majority $(73 \%) \geq 0.90$. Regression equations within a species were similar among harvests. The equations

$$
\begin{aligned}
& \mathrm{RL}=2353 \mathrm{x}+35.4\left(R^{2}=0.98\right) \text { and } \\
& \mathrm{RA}=203 \mathrm{x}-0.6\left(R^{2}=0.94\right)
\end{aligned}
$$

represent 'Sarah' mountain laurel, and the equations

$$
\begin{aligned}
& \mathrm{RL}=978 \mathrm{x}+22.5\left(R^{2}=0.92\right) \text { and } \\
& \mathrm{RA}=82 \mathrm{x}-1.7\left(R^{2}=0.94\right)
\end{aligned}
$$

represent 'Compacta' holly, where $\mathrm{x}=\mathrm{DW}$ of non-dyed roots. This method of determining RLand RAfrom a subsample was in agreement with the procedure employed by Thetford et al. (1995).

Data were analyzed using a general linear models procedure (SAS Institute, Inc., 1988). Statistical analysis indicated a significant DAP $\times$ species interaction $(P<0.0001)$ for all measured variables; therefore, regression analyses (SAS Institute, 1988) performed for all measurements plotted against DAP were separated by species. Since at experiment initiation there was no new root tissue, regression analysis for all root variables included setting the y-intercept equal to zero. Regression analyses were used only as descriptive rather than predictive tools.

Regression analysis was also used to describe several relationships between root and shoot measurements. To allometrically
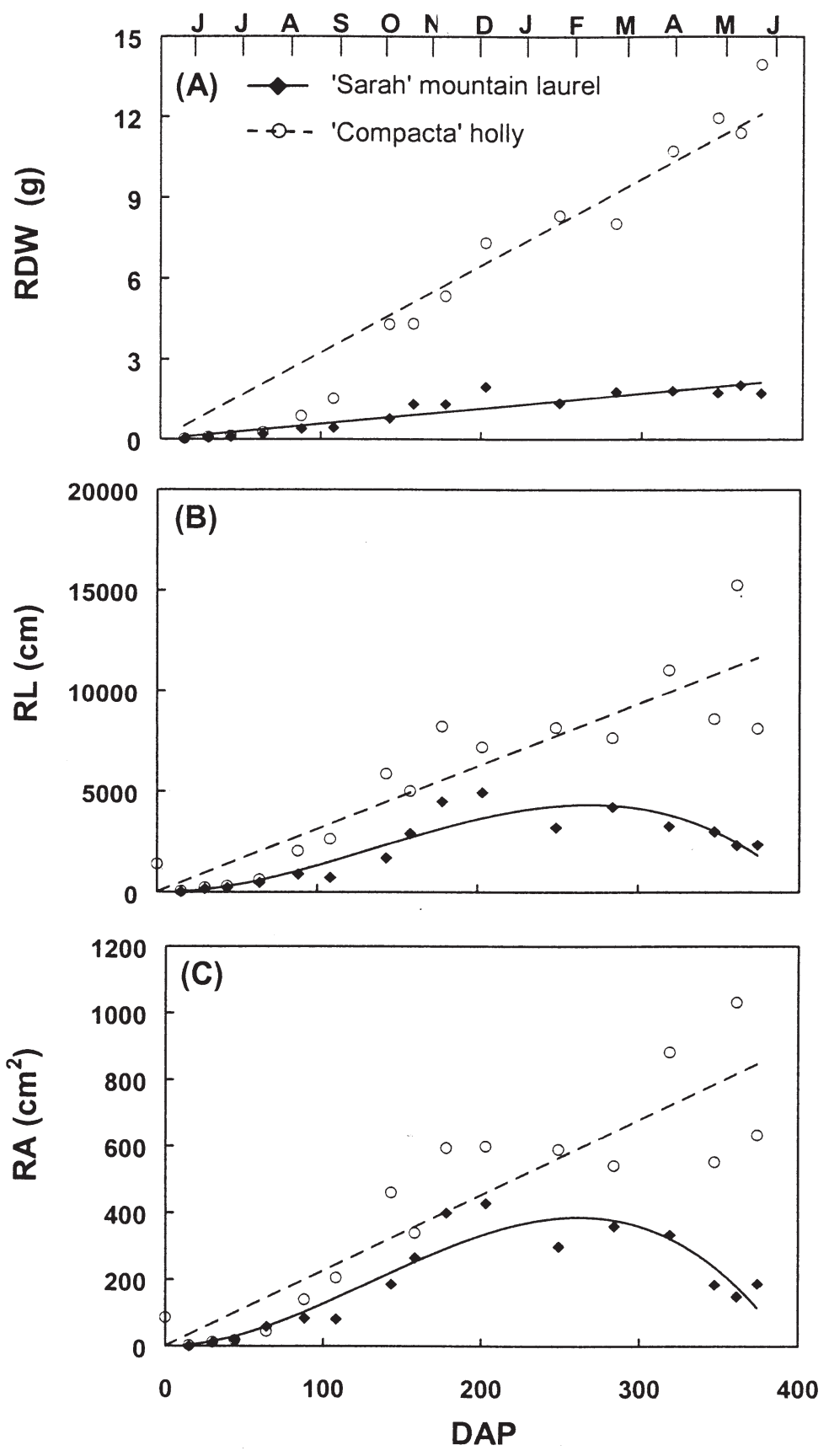

Fig. 1. (A) Root dry weight (RDW) at each harvest for 'Sarah' mountain laurel $\left(\mathrm{y}=0.006 \mathrm{x}, R^{2}=0.85\right)$ and 'Compacta' holly $\left(\mathrm{y}=0.03 \mathrm{x}, R^{2}=0.94\right)$; (B) root length $(\mathrm{RL})$ at each harvest for 'Sarah' mountain laurel $\left(\mathrm{y}=-0.0005 \mathrm{x}^{3}+0.19 \mathrm{x}^{2}-0.89 \mathrm{x}, R^{2}=0.84\right)$ and 'Compacta' holly $\left(\mathrm{y}=31.21 \mathrm{x}, R^{2}=0.83\right)$; and $(\mathbf{C})$ root area (RA) at each harvest for 'Sarah' mountain laurel $\left(\mathrm{y}=-0.00004 \mathrm{x}^{3}+0.02 \mathrm{x}^{2}+0.04 \mathrm{x}, R^{2}=0.86\right)$ and 'Compacta' holly $\left(\mathrm{y}=2.27 \mathrm{x}, R^{2}=0.82\right)$. Harvest time is represented as days after potting (DAP). In all cases, slopes for the two species are significantly different $(P<0.0001)$. Symbols represent the mean of five observations. Values for RDW, RL, and RA represent measurements non-dyed roots.

describe plant development, RDW was plotted against SDW (Ledig et al., 1970). Change in root : shoot ratio over time was determined by plotting RDW : SDW against DAP (Brouwer, 1983; Wilson, 1988). Dry weight ratios (DWRs) were plotted against DAP to describe the relative distribution of dry matter between plant organs over time (Drew and Ledig, 1980). DWRs for stems, leaves, and roots were calculated as described by Thetford et al. (1995) and represented the percentage of the total plant DW comprised of stems, leaves, or roots, respectively.

\section{Results}

New root growth of 'Compacta' holly and 'Sarah' mountain laurel was measurable 15 and 30 DAP, respectively. Root DW increased linearly over time for both species, and the slope of this increase was five times smaller for 'Sarah' mountain laurel than for 'Compacta' holly (Fig. 1A). Increase in RL and RA over time was best fit by linear regression for 'Compacta' holly and cubic regression for 'Sarah' mountain laurel (Fig. 1 B and C). The significant $\mathrm{DAP} \times$ species interaction for 
Fig. 2. (A) Leaf area (LA) at each harvest for 'Sarah' mountain laurel $\left(\mathrm{y}=1.29 \mathrm{x}+250.4, R^{2}=0.69\right)$ and 'Compacta' holly $\left(\mathrm{y}=1.36 \mathrm{x}+181.64, R^{2}=\right.$ $0.66)$; and (B) shoot dry weight (SDW) at each harvest for 'Sarah' mountain laurel $(\mathrm{y}=0.04 \mathrm{x}+$ $\left.3.05, R^{2}=0.91\right)$ and 'Compacta' holly $(\mathrm{y}=0.04 \mathrm{x}$ $+2.12, R^{2}=0.89$ ). Harvest time is represented as days after potting (DAP). In all cases, slopes for the two species are not significantly different (LA, $P=0.56$; SDW, $P=0.96$ ). Symbols represent the mean of five observations

LA and SDW resulted from measurements for the two species occasionally overlapping throughout the experiment (Fig. 2). However, the interaction appeared to be of little practical significance since both SDW and LA increased linearly over time for both species, and there was no difference between species in the rate (slope) of these increases (Fig. 2).

When RDW was plotted against SDW, the relationship was linear for both species, and the slope of this relationship was seven times smaller for 'Sarah' mountain laurel than 'Compacta' holly (Fig. 3A). RDW : SDW increased linearly over time for 'Compacta' holly, but increased and decreased quadratically over time for 'Sarah' mountain laurel (Fig. 3B). Graphs of DWRs indicated that throughout the experiment, both stems and leaves comprised a larger percentage of the total DW than roots for 'Sarah' mountain laurel (Fig. 4A). In contrast, the root DWR of 'Compacta' holly surpassed that of both leaf and stem at 203 DAP(Fig. 4B) and remained higher through the remainder of the experiment.

\section{Discussion}

Root length and RA regressed over time for 'Sarah' mountain laurel differed from that of RDW (cubic vs. linear, respectively; Fig. 1). While one might expect RL and RA of a given species to follow similar patterns over time (RLand RA were highly correlated, $R^{2}>0.99$ ), they may differ dramatically from patterns for RDW. Differences between changes in DW and changes in actual surface area have been documented (Brouwer, 1983). As a perennial root matures, it may lose epidermal as well as cortical tissue, and the root becomes lignified. Thus, as root diameter and root surface area decrease, root DW may actually increase as more structural tissue is laid down (Esau, 1965) or as roots begin to function as a storage organ during the winter. When these changes in anatomy occur, RL and RA may provide more insight about root growth patterns and absorbing capabilities than RDW alone (Harris,

Fig. 3. (A) Root dry weight (RDW) plotted against shoot dry weight (SDW) for 'Sarah' mountain laurel $\left(\mathrm{y}=0.12 \mathrm{x}-0.29, R^{2}=0.76\right)$ and 'Compacta' holly $\left(\mathrm{y}=0.82 \mathrm{x}-2.58, R^{2}=0.88\right)$; and (B) RDW : SDW at each harvest for 'Sarah' mountain laurel $\left(\mathrm{y}=-0.000002 \mathrm{x}^{2}+0.0009 \mathrm{x}\right.$, $\left.R^{2}=0.73\right)$ and 'Compacta' holly $(\mathrm{y}=0.002 \mathrm{x}$, $\left.R^{2}=0.95\right)$. Time of harvest is represented as days after potting (DAP). In all cases, slopes of the two species are significantly different $(P$ $<0.0001)$. Symbols represent the mean of five observations.
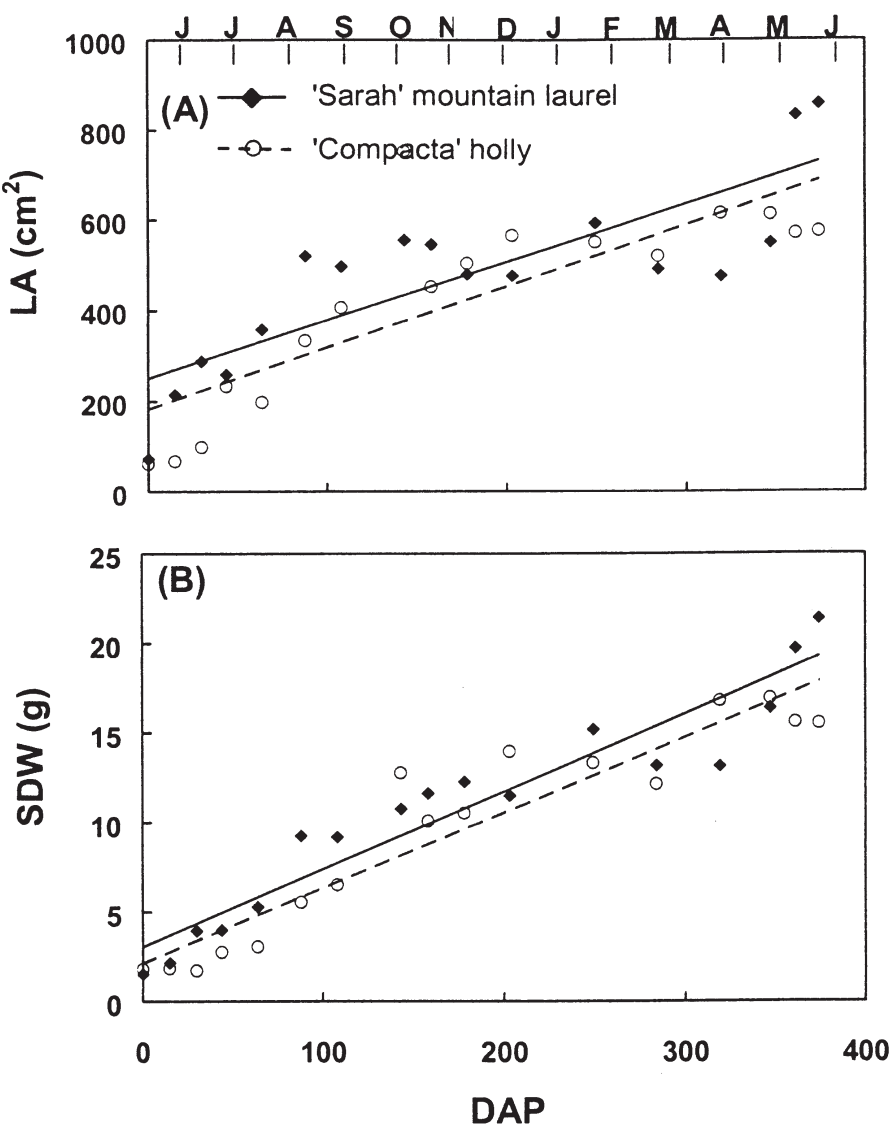

Fig. 2.
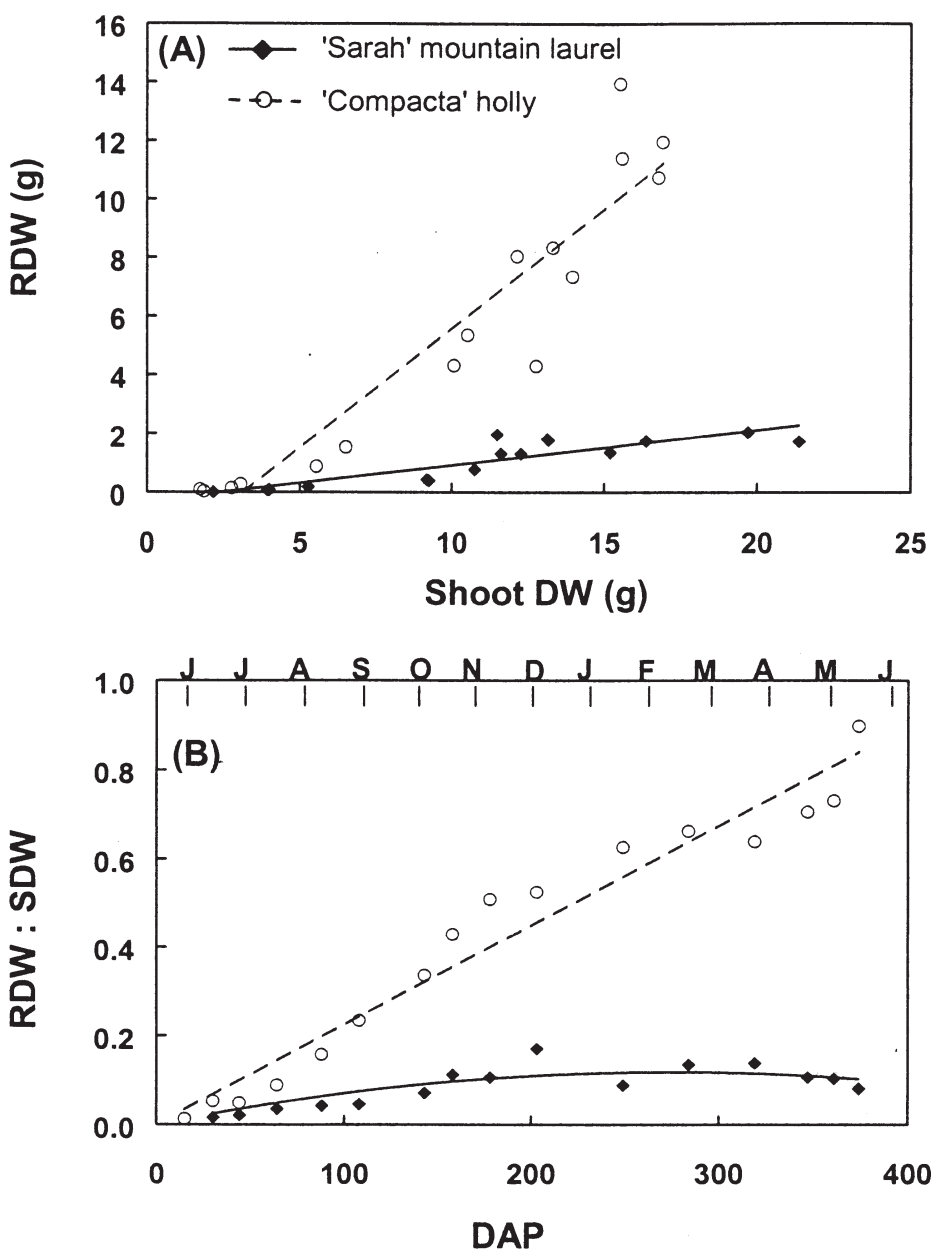

Fig. 3. 


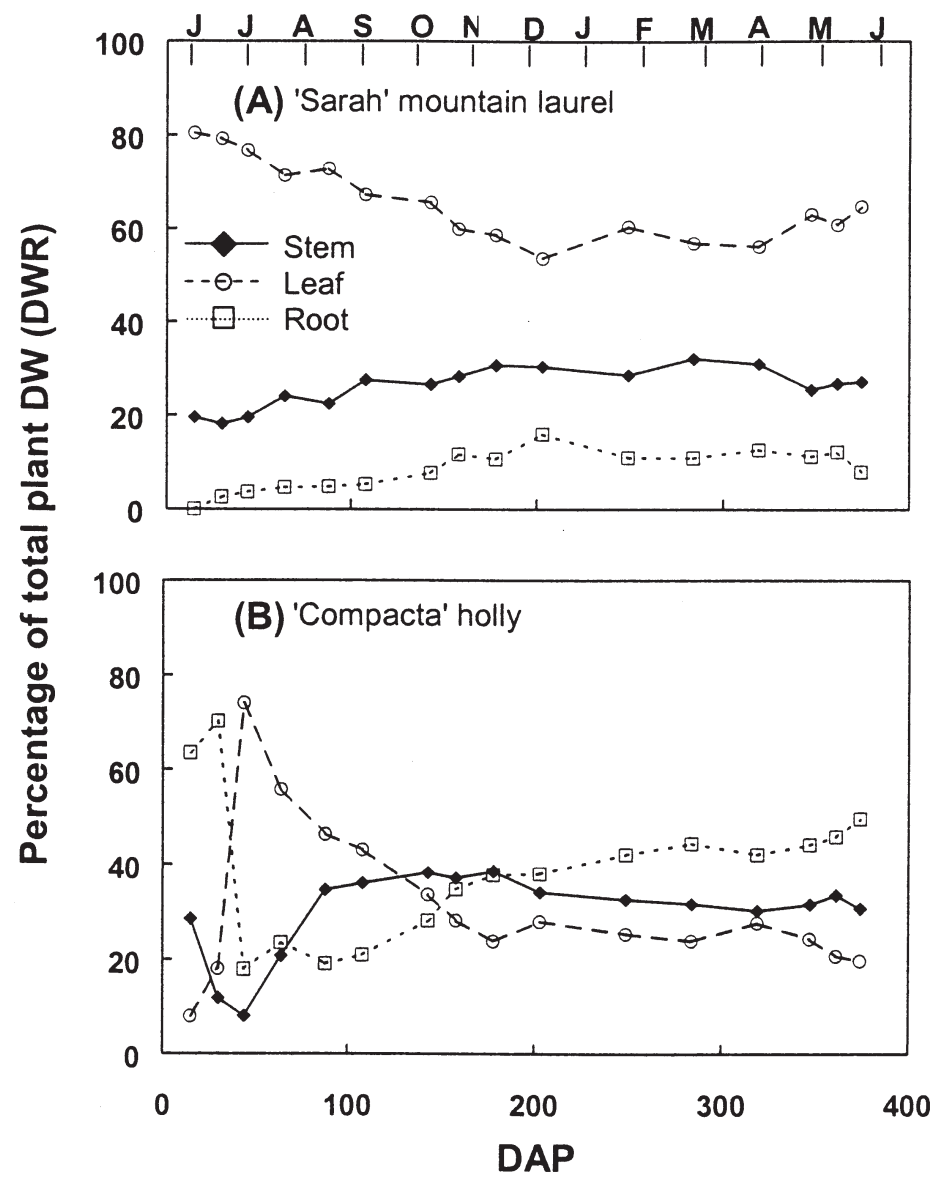

.Fig. 4. Dry weight ratios (DWRs) at each harvest for (A) 'Sarah' mountain laurel and (B) 'Compacta' holly. DWR is the percentage of the total plant DW comprised of stems, leaves, or roots. Time of harvest is represented as days after potting (DAP). Symbols represent the mean of five observations.

1992). Increased RL will increase exploration of surrounding soil following transplanting, and the associated larger root surface area will likely enhance water uptake (Kramer and Bullock, 1966). We do not attribute the decrease in RL and RA to winter injury or predation by soil organisms since these events would also result in a decrease in RDW. Although the roots present in the original rootball likely grew during the course of the experiment, the inability to adequately separate these from the original pine bark substrate prevented their measurement. Nonetheless, new root growth that extends into the surrounding soil has more importance during transplant establishment. The difference in RL and RA between 'Compacta' holly and 'Sarah' mountain laurel may help explain their contrasting survival rates following transplanting.

The cubic fit of RL and RA over time for 'Sarah' mountain laurel exhibits the steepest slope during September to December (108 to 203 DAP) and a negative slope during January to May (249 to 374 DAP) (Fig. 1). This result suggests that fall transplanting may improve transplant survival of mountain laurel due to more rapid increase in RL and RA during fall months. Benefits of fall transplanting have been reported for fringetree (Chionanthus virginicus $\mathrm{L}$.), which exhibited more root and shoot growth after one growing season when transplanted in November than in March (Har- ris et al., 1996). The benefit of fall transplanting has also been shown when transplanting liners of woody nursery stock into larger containers (Laiche, 1991). Laiche (1991) reported that "considerable root growth" was observed during the winter months when liners were potted in September. In addition to root growth during the winter, plants potted in September produced the most root and shoot growth after one growing season compared to plants potted in April or May. Kozlowski and Davies (1975) suggested plants that exhibit seasonal growth periodicity should be transplanted during the time of the year when root growth rates are highest. Although plants in our study remained in containers and thus required some protection from freezing during the winter, our plants did encounter seasonal temperature fluctuations that resulted in changes in root growth patterns. Our data suggest that time of transplanting may not be critical for Japanese holly as evidenced by 'Compacta' holly's consistent year-round root growth.

The decrease in RL and RA of 'Sarah' mountain laurel during January to May (249 to 374 DAP; Fig. 1 A and B), in conjunction with an increase in SDW and LA during this time (Fig. 2 A and B) suggest that mountain laurel exhibits seasonal patterns of root mortality and root and shoot growth. Thus, dry matter allocation appeared to favor roots from September through December and shoots from January through May. Despite decreased RL and RA of 'Sarah' mountain laurel in the spring, we would have expected a subsequent increase in RL and RA following spring shoot flushes had the experiment continued for another year (Drew and Ledig 1980). Increases in shoot growth are frequently compensated for by subsequent increases in root growth, suggesting that feedback mechanisms exist to correct temporary imbalances in the root : shoot ratio (Cannell and Willett, 1976). Alternating growth phases were also observed by Drew and Ledig (1980) in loblolly pine (Pinus taeda L.), where seasonal variation in dry matter allocation favored roots at certain times and shoots at others. Likewise, apple (Malus Mill. sp.) produced no root growth during periods of shoot growth in the spring. Instead, roots grew during August through September after shoot growth had stopped (Rogers and Head, 1969). In contrast to 'Sarah' mountain laurel, DWR for 'Compacta' holly indicated that root production in this species continued to be favored over that of shoots, even during the spring (Fig. 4B). Since DWR for 'Compacta' holly appeared relatively constant from December (203 DAP) through the rest of the experiment, it is possible that 'Compacta' holly returned to its natural root : shoot ratio in December, and fluctuations in DWR previous to this time were the result of acclimation and adjustment following transplanting.

Although root growth differed dramatically between the two species, shoot growth was similar. The larger proportional input into shoot biomass compared to root biomass by 'Sarah' mountain laurel may correspond with this plant being adapted to shaded conditions (Ledig et al., 1970). Slow root and shoot growth of eastern hemlock [Tsuga canadensis (L.) Carriere.] has been associated with adaptation to shaded conditions, in which the plant's metabolic rates and physiology allow seedlings to survive in forest shade (Grime, 1965). A high root : shoot ratio would be more appropriate for a plant adapted to sun conditions, such as Japanese holly, that may experience higher transpiration rates (Ledig et al., 1970). In the case of tree of heaven [Ailanthus altissima (Mill.) Swingle], a faster shoot growth rate allows this plant to avoid shade and rapidly exploit the soil in a full-sun environment and suggests a more efficient root system, capable of supporting substantial shoot growth (Grime, 1965).

For a given increase in SDW, the increase in RDW for 'Sarah' mountain laurel was eight times smaller than it was in 'Compacta' holly (Fig. 3A). There was nearly a 1:1 relationship between increases in root DW and shoot DW for 'Compacta' holly, suggesting equal dry weight partitioning between roots and shoots in 'Compacta' holly. The plot of RDW : SDW over time for 'Sarah' mountain laurel (Fig. 3B) suggest that shoot growth was favored over root growth from January to May (249 to 347 DAP) in 'Sarah' mountain laurel. Our data indicate that if RL and RA measurements are unavailable, plotting RDW : SDW over time provides a better interpretation of root growth 
than plotting RDW vs. SDW or plotting RDW alone over time, since the graph of RDW : SDW over time was similar to the plots of RL and RA over time.

A higher root : shoot ratio can allow larger quantities of water and mineral nutrients to be absorbed by the plant during acclimation, possibly alleviating some of the stress associated with transplanting. The pattern of root : shoot ratio over time for 'Sarah' mountain laurel and 'Compacta' holly appears to correspond with their contrasting transplant survival rates in the landscape. For mountain laurel transplanted into the landscape from different size containers, highest survival rates occurred for plants with the highest root : shoot ratio at the time of planting (Wright et al., 2001). Unfortunately, specific recommendations regarding root : shoot ratio are not known for many species (Andersen et al., 2000).

Finally, there was a 30 DAP delay by 'Sarah' mountain laurel in production of new roots following potting. Delay in new root growth following transplanting has been documented in other species (Harris et al., 1996). Time to initiation of new root growth is important in predicting or describing transplant success, since initiation of new root growth shortly after transplanting has been correlated with successful transplant establishment (Woods, 1959). Root growth may explain, at least in part, the difference in survival rates for different species (Harris et al., 1996; Struve and Moser, 1984). Because of the similarity in shoot growth between the two species throughout the experiment, data herein support the hypothesis that mountain laurel's poor transplant performance in the landscape is related to its slow rate of root growth.

\section{Literature Cited}

Andersen, L., H.N. Rasmussen, and P.E. Brander. 2000. Regrowth and dry matter allocation in Quercus robur $\mathrm{L}$. seedlings root pruned prior to transplanting. New Forests 19:205-213.

Arnold, M.A. and E. Young. 1990. Use of dyes to facilitate measurement of new root growth of apple. HortScience 25:116-118.

Brouwer, R. 1983. Functional equilibrium: Sense or nonsense? Neth. J. Agr. Sci. 31:335-348.

Cannell,M.G.R. and S.C. Willett. 1976. Shoot growth phenology, dry matter distribution and root:shoot ratios of provenances of Populus trichocarpa, Picea sitchensis, and Pinus contorta growing in Scotland. Silvae Genetica 25:49-59.

Drew, A.P. and F.T. Ledig. 1980. Episodic growth and relative shoot:root balance in loblolly pine seedlings. Ann. Bot. 45:143-148.

Esau, K. 1965. Plant anatomy. 2nd ed. Wiley, New York.

Grime, J.P. 1965. Comparative experiments as a key to the ecology of flowering plants. Ecology 46:513-515.

Harris, R.W. 1992. Arboriculture. 2nd ed. PrenticeHall, Englewood Cliffs, N.J.

Harris, J.R., P. Knight, and J. Fanelli. 1996. Fall transplanting improves establishment of balled and burlapped fringe tree (Chionanthus virginicus L.). HortScience 31:1143-1145.

Head, G.C. 1966. Estimating seasonal changes in the quantity of white unsuberized root on fruit trees. J. Hort. Sci. 41:197-206.

Hiller, L.K. and D.C. Koller. 1979. Potato growth responses in arcillite and sand. HortScience 14:534-536.

Jaynes, R.A. 1997. Kalmia: Mountain laurel and related species. Timber Press, Portland, Ore.

Kozlowski, T.T. and W.J. Davies. 1975. Control of water balance in transplanted trees. J. Arboricult. 1(1):1-10.

Kramer,P.J. and H.C. Bullock. 1966. Seasonal variations in the proportions of suberized and unsuberized roots of trees in relation to the absorption of water. Amer. J. Bot. 53:200-204.

Laiche,A.J., Jr. 1991. Time of transplanting liners and initial growing location affects growth of woody nursery plants. J. Environ. Hort. 9:145-148.

Ledig, F.T., F.H. Bormann, and K.F. Wenger. 1970. The distribution of dry matter growth between shoot and roots in loblolly pine. Bot. Gaz. 131:349-359.

Pirone, P.P. 1978. Tree maintenance. 5th ed. Oxford Univ. Press, New York.

Rogers, W.S. and G.C. Head. 1969. Factors affecting the distribution and growth of roots in perennial woody species, p. 280-295. In: W.J. Whittington (ed.). Root growth. Plenum Press, New York.

SAS Institute. 1988. SAS/STAT user's guide: Release 6.03 ed. SAS Inst., Cary, N.C.

Struve, D.K., R.D. Kelly, and B.C. Moser. 1984. Promotion of root regeneration in difficult-totransplant species. Proc. Intl. Plant Prop. Soc. 33:433-439.

Struve, D.K. and B.C. Moser. 1984. Root system and root regeneration characteristics of pin and scarlet oak. HortScience 19:123-125.

Thetford, M., S.L. Warren, and F.A. Blazich. 1995 Response of Forsythia $\times$ intermedia 'Spectabilis' to uniconazole. I. Growth; dry-matter distribution; and mineral nutrient content, concentration and partitioning. J. Amer. Soc. Hort. Sci. 120:977-982.

Watson, G.W. and E.B. Himelick. 1982. Seasonal variation in root regeneration of transplanted trees. J. Arboricult. 8:305-310.

Watson, G.W. and E.B. Himelick. 1997. Principles and practice of planting trees and shrubs. Intl. Soc. Arboricult., Savoy, Ill.

Wilson, J.B. 1988. Areview of evidence on the contro of shoot : root ratio, in relation to models. Ann. Bot. 61:433-449.

Woods, F.W. 1959. Slash pine roots start growth soon after planting. J. For. 57:209.

Wright, A.N., S.L. Warren, and F.A. Blazich. 2001. Exposure and plant size affect landscape establishment of Kalmia latifolia. Proc. SNA Res. Conf., 46th Annu. Rpt. p. 515-518. 